[Regular Paper]

\title{
Effects of Film Thickness, Wavelength, and Carbon Black on Photodegradation of Asphalt
}

\author{
Katsuyuki YAmaGUChI $^{\dagger 1) *}$, Iwao SASAKI ${ }^{\dagger 2)}$, Itaru NiSHIZAKI ${ }^{\dagger 2)}$, Seishi MeIARASHI ${ }^{\dagger 2)}$, and Akihiro MoriYoshI ${ }^{\dagger 3)}$ \\ 11) Chita Research Institute, Tokai Carbon Co., Ltd., 5-1 Taketoyo, Chita-Dist., Aichi 470-2341, JAPAN \\ †2) Materials and Geotechnical Engineering Research Gr., Public Works Research Institute, Independent Administrative Institute, \\ 1-6 Minamihara, Tsukuba, Ibaraki 305-8516, JAPAN \\ †3) Graduate School of Engineering, Hokkaido University, Nishi 8-chome, Kita 13-jo, Kita-ku, Sapporo 060-8628, JAPAN
}

(Received October 8, 2004)

\begin{abstract}
Focusing on sunlight that has severe effects on the degradation of asphalt pavement during service, this study examined the relationships between the film thickness of asphalt and the states of photodegradation. The results confirmed that thinner films had a higher modulus of elasticity, lower viscosity, and increased production of carbonyl groups, which is an indicator of oxidative degradation. The degree of degradation rapidly increased especially at thicknesses below $200 \mu \mathrm{m}$. The wavelength dependence of spectral photodegradation was also examined. Visual observations and the carbonyl index confirmed that ultraviolet irradiation in the range of 300 to 400 $\mathrm{nm}$ caused severe photodegradation of asphalt. Carbon black blocked light near the surface of the asphalt layer, where the damage caused by light is most severe. Addition of carbon black helps to prevent photodegradation by ultraviolet irradiation in the wavelength range of 300 to $400 \mathrm{~nm}$.
\end{abstract}

\section{Keywords}

Asphalt, Photodegradation, Ultraviolet irradiation, Film thickness, Wavelength, Carbon black

\section{Introduction}

Asphalt materials, as well as other organic materials, are easily degraded by heat or sunlight, and become harder and more brittle as degradation proceeds. In the case of asphalt used for pavements, heat is the dominant cause of degradation during construction, when asphalt is subjected to higher temperatures. On the other hand, light, especially ultraviolet irradiation ${ }^{1), 2)}$, is closely related to asphalt degradation during service. Many studies on the degradation behavior of asphalt have used thin film specimens, because the asphalt in mixtures coats the aggregates in thin-film form. However, most of these methods used for indoor accelerated aging tests include heat treatment ${ }^{3), 4}$. The photodegradation of asphalt is remains unclear, because methods for testing have not been fully established in the same way as for thermal aging.

The first objective of this study was to examine the effects of the film thickness of asphalt on photodegradation. The degree of photodegradation of asphalt is most severe at the surface of the asphalt layer and decreases with increasing depth ${ }^{5) \sim 7)}$. The changes in composition of asphalt caused by ultraviolet irradiation

\footnotetext{
* To whom correspondence should be addressed.

* E-mail: kyamaguc@tokaicarbon.co.jp
}

are larger in mixtures than in 3-mm thick film ${ }^{8}$. These reports suggest that the film thickness of asphalt affects the degree of degradation by light as well as by heat. Increasing the asphalt content and/or decreasing air voids in asphalt mixtures are considered to be effective ways of preventing longitudinal surface cracking, which is called top-down cracking ${ }^{9), 10)}$. These measures increase the film thickness of asphalt. In this study, thin film specimens in the range of 50 to $1000 \mu \mathrm{m}$ were prepared using the "press method"11). Each specimen was examined for degradation behavior by indoor accelerated photodegradation tests.

The second objective was to examine the wavelength dependence of photodegradation of asphalt. In the field of plastics, previous researches have been conducted to predict the lifetime and to develop durable materials. For example, photodegradation of PMMA (polymethyl methacrylate) is caused by irradiation of wavelengths below $320 \mathrm{~nm}^{12}$. PVC (polyvinyl chloride) undergoes light-induced yellowing by irradiation below $340 \mathrm{~nm}^{13)}$. In this study, the wavelength susceptibility of photodegradation of asphalt was examined using a spectral aging device. The results will provide effective countermeasures against asphalt degradation.

The third objective of this study was to examine the effects of adding carbon black on the photodegradation of asphalt. Carbon black ${ }^{14)}$ is well known as a weather- 
Table 1 Properties of Asphalt Binder

\begin{tabular}{lrll}
\hline \multicolumn{2}{c}{ Test item } & StAs & \multicolumn{1}{c}{ Test specification } \\
\hline Penetration at $25^{\circ} \mathrm{C}$ & {$[1 / 10 \mathrm{~mm}]$} & 90 & JIS K 2207-6.3 \\
Softening point & {$\left[{ }^{\circ} \mathrm{C}\right]$} & 46.0 & JIS K 2207-6.4 R\&B \\
Viscosity at $135^{\circ} \mathrm{C}$ & {$[\mathrm{mPa} \cdot \mathrm{s}]$} & 365 & JIS K 2207-6.14 Cannon-Fenske \\
Density at $15^{\circ} \mathrm{C}$ & {$\left[\mathrm{g} / \mathrm{cm}^{3}\right]$} & 1.033 & JIS K 2207-6.12 Hubbard bottle \\
Flash point & {$\left[{ }^{\circ} \mathrm{C}\right]$} & 348 & JIS K 2265-7 COC \\
\hline
\end{tabular}

Table 2 Properties of Carbon Black (Tokai Carbon Co., Ltd. \#7350F)

\begin{tabular}{lrrl}
\hline \multicolumn{1}{c}{ Test item } & CB & \multicolumn{1}{l}{ Test specification } \\
\hline Surface area by N N $^{2}$ adsorption & {$\left[\mathrm{m}^{2} / \mathrm{g}\right]$} & 80 & JIS K 6217-7 BET \\
DBP absorption $^{\text {a) }}$ & {$\left[\mathrm{cm}^{3} / 100 \mathrm{~g}\right]$} & 100 & JIS K 6217-9 \\
Aggregate size Dst $^{\mathrm{b})}$ & {$[\mathrm{nm}]$} & 90 & ASTM D 3849 DCF
\end{tabular}

a) Void volume of bulk carbon black using dibutylphthalate as absorbate.

b) Equivalent Stokes' diameter measured by disc centrifuge (DCF).

proofing filler in the polymer industry. The present authors ${ }^{11), 15)}$ previously confirmed that carbon black hinders the ultraviolet degradation of asphalt materials. In this study, we examined the effects of adding carbon black on the depth of damage from light, and the degradation rate. Furthermore, the relationships between wavelength and degradation caused by the addition were also examined in spectroscopic experiments.

\section{Experiment}

\section{1. Sample Materials}

The base asphalt was commercially available straight asphalt (StAs) with the basic properties listed in Table 1. Carbon black was \#7350F (Tokai Carbon Co., Ltd.) with the basic properties shown in Table 2. The carbon black was pre-dried at $150^{\circ} \mathrm{C}$ for $24 \mathrm{~h}$ and then kneaded with StAs for $45 \mathrm{~min}$ in a mixer (Dalton, universal mixer 2XDMV-Qr) with bath temperature of $60^{\circ} \mathrm{C}$. The kneading at high viscosity provided high shear force and uniform dispersion of carbon black in the asphalt without lump formation. The StAs with 10 wt\% carbon black was named CB10.

\section{2. Preparation of Thin Film Specimens}

Thin film specimens were prepared by the press method $^{11)}$ which was developed by the authors. The asphalt sample was sandwiched between poly-tetra-fluoro-ethylene (PTFE) sheets, then pressed into a thin film at $60^{\circ} \mathrm{C}$. Specimens with five different thicknesses of 50,100, 200, 500, and $1000 \mu \mathrm{m}$ were prepared by using samples after the thin film oven test ${ }^{16)}$.

As a preliminary experiment, asphalt collected from the $50 \mu \mathrm{m}$ thick specimen shortly after the pressing process was subjected to physical and chemical evaluation tests as described in section 2. 4. The results confirmed that the asphalt samples were degraded less by the operation of pressing and mixing uniformly at $150^{\circ} \mathrm{C}$ for $30 \mathrm{~min}$ in vacuum after collecting the sam- ples.

2. 3. Photodegradation Tests

2. 3. 1. Effects of Film Thickness on Photodegradation of Asphalt

Indoor accelerated aging treatments were applied to examine the photodegradation behavior of asphalt effectively and repeatedly. The Atlas Sun-test XLS was used to examine the effects of the film thickness on photodegradation. This device consists of a xenon arc lamp and special filter to simulate the spectral distribution of sunlight. The exposure intensity of the xenon lamp was set at $78 \mathrm{~W} / \mathrm{m}^{2}$ in the wavelength range of 300 to $400 \mathrm{~nm}$. Light was irradiated for $48 \mathrm{~h}$ at an integrated ultraviolet irradiation dose of $13.4 \mathrm{MJ} / \mathrm{m}^{2}$. This condition corresponds to outdoor exposure for one to two months ${ }^{11)}$. The black standard temperature was set at $60^{\circ} \mathrm{C}$, which is equivalent to the surface temperature of pavement in summer.

\section{3. 2. Effects of Wavelength on Photodegradation of Asphalt}

A spectral ultraviolet irradiation aging device (Suga Test Instruments Co., Ltd.) with a xenon arc lamp was used to examine the effects of wavelength on the photodegradation of asphalt. The sensor window, measuring $60 \mathrm{~mm}$ wide by $40 \mathrm{~mm}$ high, was subjected to light of wavelengths from 250 to $550 \mathrm{~nm}$. Exposure intensity at the wavelength of $300 \mathrm{~nm}$ was set at 36 $\mathrm{W} / \mathrm{m}^{2}$. Spectral light was irradiated for $48 \mathrm{~h}$. The ambient temperature was controlled at $25^{\circ} \mathrm{C}$. The film thickness of asphalt was $100 \mu \mathrm{m}$ to provide sufficient samples for the evaluation test, FT-IR spectroscopy, and to ensure the light had an effect throughout the thickness of the film.

\section{4. Test Items}

\section{4. 1. Dynamic Shear Rheometer Test}

Dynamic viscoelastic properties were examined using a dynamic shear rheometer, Rheometrix RAA, according to the SHRP-B003 ${ }^{17)}$ method. Measure- 
ments were performed at a frequency of $10 \mathrm{rad} / \mathrm{s}$ and a parallel plate of $8 \mathrm{~mm}$ in diameter was used with a gap of $2 \mathrm{~mm}$. The test temperature was controlled at $20^{\circ} \mathrm{C}$. $G^{*}$ is the dynamic complex modulus, and $\delta$ is the phase angle between stress and strain. An increase of $\left|G^{*}\right|$ and a decrease of $\delta$ means that the asphalt materials stiffen and become brittle, respectively. Both are indicators of the degradation of asphalt.

\section{4. 2. Fourier Transform Infrared Spectroscopy (FT-IR)}

FT-IR was used to examine the behavior of oxygencontaining functional groups, or carbonyl groups, which is an indicator of oxidative degradation of asphalt materials ${ }^{18)}$. Spectra were recorded on a FTIR spectrometer, Spectrum One (Perkin Elmer, Inc.), with a resolution of $4 \mathrm{~cm}^{-1}$. A chloroform solution of $0.03 \mathrm{~g} / \mathrm{cm}^{3}$ was placed in a $\mathrm{KBr}$ liquid cell with $0.1 \mathrm{~mm}$ spacer.

The evaluation used the carbonyl index $(C I)$ shown in Eq.(1), because the transmittance of infrared light is affected by the degradation and the addition of carbon black. The index is the absorbance ratio between the bands around 1600 and $1700 \mathrm{~cm}^{-1}$. The former band is caused by the stretching vibration of the $\mathrm{C}=\mathrm{C}$ bond and is independent of degradation ${ }^{18)}$. This band was used as an internal reference. The latter is caused by the stretching vibration of the $\mathrm{C}=\mathrm{O}$ bond. The background range was set at 1825 to $550 \mathrm{~cm}^{-1}$.

$$
C I=\frac{\log \left(I_{01} / I_{1}\right)}{\log \left(I_{02} / I_{2}\right)}
$$

where $I_{1}, I_{2}$ are the transmittances of the bands around 1700 and $1600 \mathrm{~cm}^{-1}$, and $I_{01}, I_{02}$ are the background transmittances, respectively.

\section{Results and Discussion}

\section{1. Effects of Film Thickness on Photo- degradation of Asphalt}

\section{1. 1. Change in Dynamic Viscoelastic Properties with Film Thickness}

Figures 1a) and 1b) show the dynamic viscoelastic properties $\left(\left|G^{*}\right|\right.$ and $\delta$, respectively) of the asphalt specimens with film thicknesses of 50, 100, 200, 500, and $1000 \mu \mathrm{m}$ after photodegradation. The levels of both properties before photodegradation are also superimposed as parallel lines on the transverse axis on each figure. Each asphalt sample after aging treatment was uniformly mixed, then the sample was evaluated. Therefore, each marker in Figs. 1a) and 1b) shows the average viscoelastic properties in the region from the surface to the greatest depth of the asphalt layer (Fig. 2).

$\left|G^{*}\right|$ increased and $\delta$ decreased in thinner asphalt films. Assuming that the degree of degradation at the same depth is horizontally uniform regardless of sam-

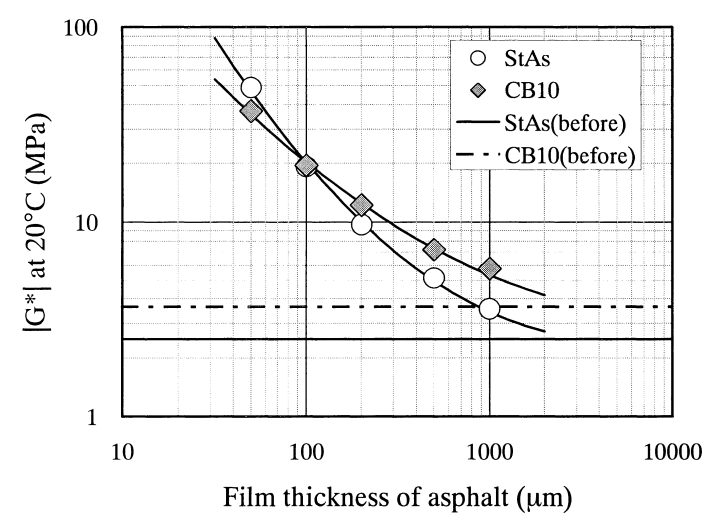

a) $\left|G^{*}\right|$ at $20^{\circ} \mathrm{C}$

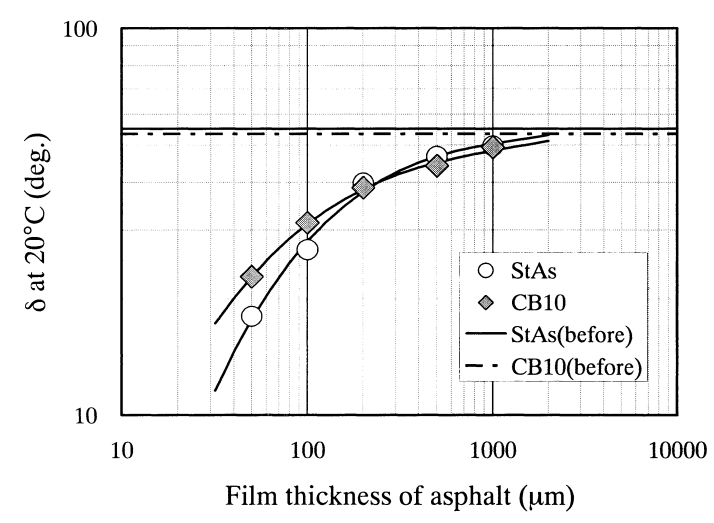

b) $\delta$ at $20^{\circ} \mathrm{C}$

Fig. 1 Effects of Film Thickness on Photodegradation of Asphalt with and without Carbon Black

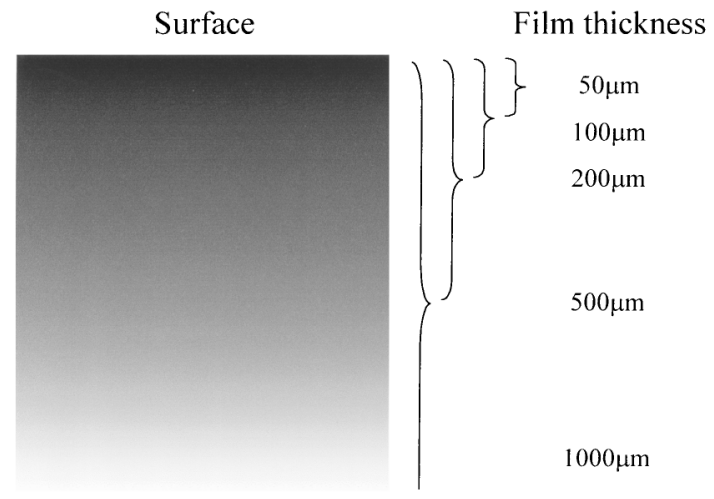

Fig. 2 Schematic Diagram of Thin Film Specimens

ple thickness, degradation in the region from the surface to the depth of $100 \mu \mathrm{m}$, for example, should be the same in specimens with thicknesses of 100 and 1000 $\mu \mathrm{m}$. Therefore, the results show that the degree of degradation worsens toward the surface of the asphalt layer, and rapidly increases in the thickness range below $200 \mu \mathrm{m}$. Consequently, increasing the film 


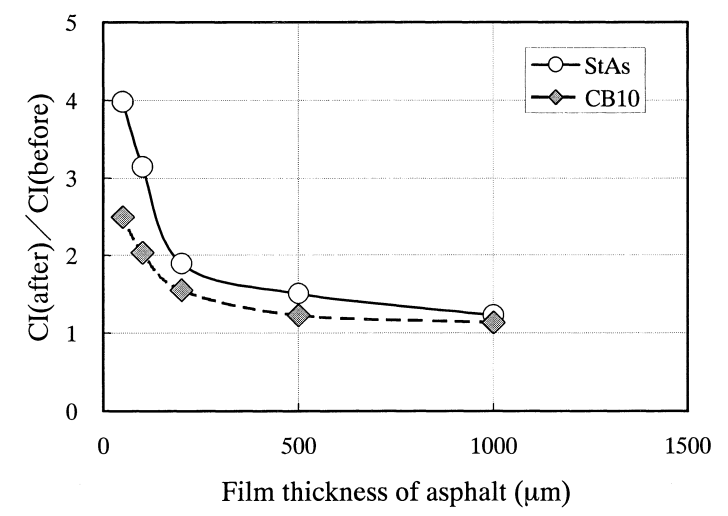

Fig. 3 Effects of Film Thickness and Carbon Black Addition on the Changes in Carbonyl Index by Photodegradation

thickness by increasing the asphalt content in the asphalt mixture, even if only slightly, will improve the durability of pavement due to the prevention of photodegradation of asphalt.

$\left|G^{*}\right|$ of CB10 was larger than that of StAs because of the reinforcing effects of carbon black. However, $\mid G^{*}$ | of CB10 was equivalent to that of StAs after photodegradation at the film thickness of $100 \mu \mathrm{m}$. I $G^{*}$ | of CB10 was not as large as that of StAs at the film thickness of $50 \mu \mathrm{m}$. The decrease in $\delta$ was smaller for CB10 than for StAs in the thickness range below 200 $\mu \mathrm{m}$. Therefore, the addition of carbon black to asphalt seems to prevent photodegradation.

\section{1. 2. Change of Carbonyl Index with Film Thickness}

Figure 3 shows the ratios of the carbonyl indexes after aging $(C I$ (after)) to before aging (CI (before)), (= $C I$ (after)/CI (before)) for both StAs and CB10, indicating the changes in chemical properties by photodegradation.

The carbonyl index, which is an indicator of oxidative degradation, increased rapidly with decrease of film thickness of asphalt. Therefore, degradation is more severe near the surface because oxygen, which is needed to produce carbonyl groups, is supplied from the surface of the asphalt layer. The tendency of the carbonyl index to increase rapidly in the thickness range below $200 \mu \mathrm{m}$ was the same as that found in the dynamic shear rheometer test. These results of the aging conditions (exposure intensity of $78 \mathrm{~W} / \mathrm{m}^{2}$ in the wavelength range of 300 to $400 \mathrm{~nm}$ for $48 \mathrm{~h}$ ) used in this study correspond to the degradation behavior at the early stage of 1 to 2 months' outdoor exposure. However, as the average film thickness in asphalt mixtures is calculated to be about $10 \mu \mathrm{m}^{3)}$ from the relationship between asphalt content and apparent surface areas of aggregates, this aging time is sufficient. Although the actual film thickness will not be uniform but includes thick and thin areas, the light will reach the whole of the film near the surface of the asphalt

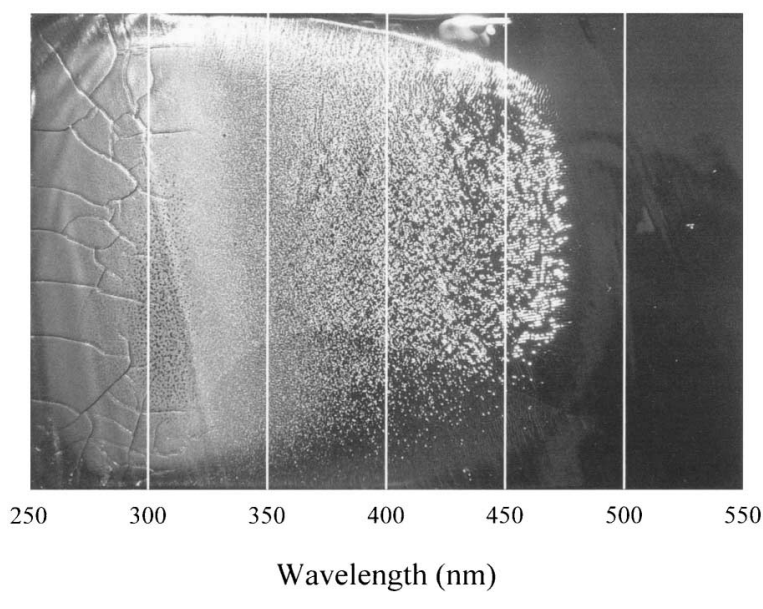

Fig. 4 Appearance of StAs after Spectral Photodegradation

layer, and oxidative degradation will proceed.

The carbonyl index in the CB10 specimen changed little in the thickness range below $200 \mu \mathrm{m}$. This tendency was similar to the behavior of the viscoelastic properties. These results indicate that carbon black blocks the penetration of light near the surface of the asphalt layer.

\section{2. Effects of Wavelength on Photodegradation of Asphalt}

\section{2. 1. Change in Appearance Caused by Spectral Photodegradation}

Figure 4 shows the appearance of the StAs specimen after spectral photodegradation. The spectroscopic device simulates the spectral distribution of sunlight, so the appearance reflects the relationship between wavelength and degradation of actual pavement.

The sample in the wavelength range of 475 to 550 $\mathrm{nm}$ remained black and glossy after photodegradation. The appearance suggested that light over $550 \mathrm{~nm}$ has little impact on degradation. On the other hand, some creases were observed in the range of 450 to $475 \mathrm{~nm}$. The sample lost its gloss with decreasing wavelength and became gray in the region below $400 \mathrm{~nm}$. Furthermore, many cracks were observed in the range of 250 to $300 \mathrm{~nm}$. The changes in the appearance of the CB10 specimen were similar to those of StAs, but CB10 had few cracks in the wavelength range of 250 to $300 \mathrm{~nm}$.

\section{2. 2. Correlation between Carbonyl Index and Wavelength}

After spectral photodegradation, samples on the sensor window were collected at $50 \mathrm{~nm}$ intervals (white lines shown in Fig. 4) in the range of 250 to $550 \mathrm{~nm}$. The carbonyl index of the collected samples was measured by FT-IR spectroscopy. However, these results cannot be compared with the degradation level mentioned in section item 3. 1. because the aging conditions, such as exposure intensity distribution for the wave- 


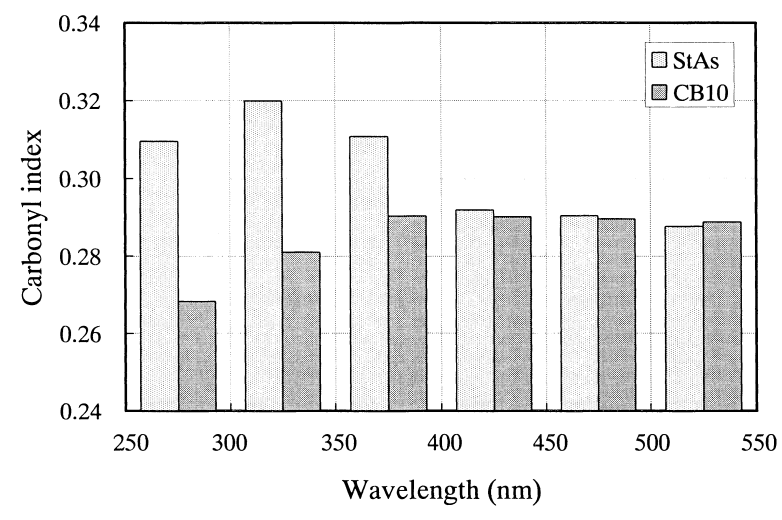

Fig. 5 Effects of Wavelength and Carbon Black Addition on Photodegradation of Asphalt

length, were different. Thus, only the wavelength dependence of the degree of degradation was examined. Figure 5 shows the carbonyl indexes of collected samples for both StAs and CB10.

The carbonyl index of StAs increased in the wavelength range below $400 \mathrm{~nm}$. It is estimated that only light of more than about $300 \mathrm{~nm}^{19)}$ reaches the earth's surface because of adsorption by ozone in the atmosphere. Thus, it is highly likely that ultraviolet irradiation in the wavelength range of 300 to $400 \mathrm{~nm}$ is the key factor for actual in-service pavements. The present authors ${ }^{1), 11)}$ found that the degree of degradation of asphalt is unambiguously defined by integrated ultraviolet irradiation in the wavelength range of 300 to 400 $\mathrm{nm}$. The results of this study support the previous findings.

The degradation behavior of the asphalt containing carbon black, CB10, was clearly different from that of StAs. The carbonyl index of CB10 decreased in the wavelength range below $400 \mathrm{~nm}$. Plastics such as polyethylene and polypropylene are considered to be degraded by reaction with free radicals produced by ultraviolet irradiation with oxygen and/or polymer molecules. A possible explanation for the effect of carbon black is that functional groups on the surface of carbon black act as free radical scavengers ${ }^{14)}$. In the case of asphalt, it is difficult to identify the role of carbon black because asphalt consists of many complex hydrocarbons. However, the above-mentioned unusual degradation behavior is attributed to the fact that carbon black blocks ${ }^{14), 20)}$ ultraviolet irradiation in this wavelength range and prevents oxidative degradation.

The use of various modified asphalts with resins and/or thermoplastic elastomer has recently become common to improve rutting resistance. However, degradation during service has a significant impact on crack resistance. Carbon black is potentially useful because the addition of only a few percent improves the weatherability of asphalt. This study focused exclusively on unmodified straight asphalt, but carbon black is also expected to be effective for modified asphalt in combination with polymer modifiers.

\section{Conclusions}

The effects of the film thickness of asphalt, wavelength, and addition of carbon black were examined on the degradation of asphalt. The following findings were obtained.

Thinner film thickness of asphalt resulted in a higher modulus of elasticity $\left|G^{*}\right|$, lower viscosity $\delta$, and increase of carbonyl index, which is an indicator of oxidative degradation. The degree of degradation rapidly increased, especially in the thickness range below $200 \mu \mathrm{m}$. Light has an impact on the entire film near the surface of the asphalt layer, because the average film thickness in asphalt mixtures is reported to be about $10 \mu \mathrm{m}$.

Visual observations and the behavior of the carbonyl index after spectral photodegradation confirmed that ultraviolet irradiation in the wavelength range of 300 to $400 \mathrm{~nm}$ has severe impacts on photodegradation of asphalt. These results support our previous study, which showed that the degradation degree of asphalt is defined unambiguously by the integrated ultraviolet irradiation in the range of 300 to $400 \mathrm{~nm}$.

Carbon black in asphalt for pavements blocks the penetration of light near the surface of the asphalt layer and thus prevents photodegradation by ultraviolet irradiation in the wavelength range of 300 to $400 \mathrm{~nm}$. Therefore, carbon black is an effective additive for improving the durability of asphalt pavements.

\section{References}

1) Sasaki, I., Yamaguchi, K., Meiarashi, S., Proceedings of the 59th Japan Society of Civil Engineers Annual Meeting, CDROM, V-543, 1083 (2004).

2) Sakanoue, S., Kobayashi, H., Sekiyu Gakkaishi (J. Jpn. Petrol. Inst.), 8, (10), 44 (1965).

3) Kandhal, P. S., Chakraborty, S., NCAT Report, 96, (1), (1996).

4) Petersen, J. C., Journal of the Association of Asphalt Paving Technologists, 158, 220 (1989).

5) Takemura, K., Monthly Report of the Civil Engineering Research Institute, 114 (1962).

6) Sato, K., Fukude, T., Hachiya, Y., Proceedings of Canada-Japan Paving in Cold Area Mini-Workshop, 102 (1982).

7) Taniguchi, T., Ito, T., Asphalt, 33, (164), 67 (1990).

8) Takeuchi, K., Murai, S., Oikawa, Y., Proceedings of the 59th Japan Society of Civil Engineers Annual Meeting, CD-ROM, V544, 1085 (2004)

9) Katawaki, S., Kawanishi, R., Nihon Doro Kaigi Ronbunshu, 19, 404 (1991).

10) Yui, D., The Japan Highway Public Corporation, Technical Information, 90, 8 (1987).

11) Yamaguchi, K., Sasaki, I., Meiarashi, S., 8th Journal of Pavement Engineering, 251 (2003).

12) Torikai, A., Ohno, M., Fueki, K., J. Appl. Polym. Sci., 41, 1023 (1990).

13) Andrady, A. L., Fueki, K., Torikai, A., J. Appl. Polym. Sci., 39, 
763 (1990).

14) Carbon Black Association, "Handbook of Carbon Black, 3rd Edition," Tokyo (1995).

カーボンブラック協会, “カーボンブラック便覧 第三版, ” 東京 (1995).

15) Yamaguchi, K., Sasaki, I., Meiarashi, S., J. Jpn. Petrol. Inst., 47, (4), 266 (2004)

16) Japan Road Association, "Manual for Test Method of Pavement," Maruzen Co., Ltd., Tokyo (1988).

（社）日本道路協会, “舗装試験法便覧, ”丸善, 東京
(1988).

17) Superior Performing Asphalt Pavements (Superpave), SHRP-A379 (1994).

18) Tanaka, K., Suzuki, I., Kajitani, I., Institute of Civil Engineering of Tokyo Metropolitan Government, Annual Report, 177 (1991).

19) "Iwanami subject-book of physics and chemistry, 5th edition," Iwanami Shoten, Tokyo (1998).

“岩波理化学事典 第五版,”岩波書店，東京 (1998).

20) Sato, K., Journal of the Japan Society of Colour Material, 54, (8), 490 (1981).

要旨

アスファルトの光による劣化に及ぼす膜厚, 波長ならびにカーボンブラック添加の影響

\author{
山口 勝之 ${ }^{\dagger 1)}$, 佐々木 厳 ${ }^{+2)}$, 西崎 到 ${ }^{\dagger 22}$, 明嵐 政司 ${ }^{\dagger 2}$, 森吉 昭博 ${ }^{\dagger 3}$ \\ †1) 東海カーボン(株) 知多研究所, 470-2341 愛知県知多郡武豊町字五号地 1 番 \\ 12) 独立行政法人土木研究所 材料地盤研究グループ, 305-8516 茨城県つくば市南原 1 番地 6 \\ †3) 北海道大学大学院工学研究科, 060-8628 札幌市北区北 13 条西 8 丁目
}

アスファルト舗装の供用中の劣化現象に影響の大きい光に注 目し，この劣化におけるアスファルト単体の膜厚の影響を調査 した。その結果, 膜厚が薄くなるにつれて, 特に $200 \mu \mathrm{m}$ 以下 の領域で，弾性率の増大や粘性の峦失，また酸化劣化を示す力 ルボニル基生成の増大など, 劣化の程度が急激に著しくなるこ とが確認された。

また，分光劣化試験による波長依存性を調査した結果，外観
変化やカルボニル指数の挙動より，アスファルトの光による劣 化には波長範囲 300～400 nm の紫外線の影響が大きいことを明 らかにした。

さらに, 遮光性フィラーとして知られるカーボンブラック は，光による劣化の著しいアスファルト層の表面付近で機能 し, 波長 300～400 nm の紫外線による劣化を抑える効果のある ことが見出された。 